\title{
NATURE OF RHIZOBIUM RADIOBACTER LIFE ACTIVITY ON THE SEEDS SURFACE AND IN ROOT ZONE OF WINTER WHEAT PLANTS
}

Trepach A. O.

Institute of Agricultural Microbiology and Agro-Industrial Manufacture NAAS of Ukraine,

97, Shevchenko Str., Chernihiv, 14027, Ukraine

E-mail: trepach@e-mail.ua

Preservation of Rhizobium radiobacter strains 599, 1333, 5006 and 5718 on inoculated seeds and further development in the rhizosphere soil of winter wheat plants of Poliska 90 variety was observed. It was found that bacterial cells $R$. radiobacter 599, 1333, 5006 and 5718 can retain on bacterized seeds of winter wheat for two months and can ecize in the root zone of plants.

Keywords: Rhizobium radiobacter, winter wheat.

Availability of phosphorus is one of the key factors for plant growth and development. However, due to the low solubility of soil phosphorus, cultivated plants experience shortage of this element [1-3]. Therefore, optimization of phosphorus nutrition of agricultural crops plays a significant role in improvement of plants productivity. In particular, this applies to winter wheat, which has a low capacity to uptake phosphorus from the soil and is particularly sensitive to its deficit during early stages of organogenesis, when plants phosphorus supply is essential to their growth, development and yield formation $[4-6]$.

Application of phosphorous mobilizing bacteria and microbial preparations on their basis in modern technologies of winter wheat cultivation can be an effective mean of crop productivity enhancement especially taking into the account the undeniable importance of phosphorus as one of the most important elements of plant nutrition.

Efficacy of phosphorous mobilizing bacteria in crop production technologies is determined in great extent by their ability to ecize in the plants root zone. Basically, survival of bacteria in the root zone of plants depends on their ability to colonize a particular area of root system and compete for it with other microorganisms [7]. Therefore, influence on the activity and orientation of plant-microbe interactions is only possible under the thorough study of bacteria competitiveness upon their introduction to the root zone of plants, their impact on the functioning of the existing microbial communities and environmental influence on its activity [8].

Given study is aimed to examine the nature of Rhizobium radiobacter life activity on seeds surface and in winter wheat roots area.

Materials and methods. Experiments were performed with Rhizobium radiobacter bacteria (strains 599, 1333, 5006, 5718), isolated by L.M. Tokmakova from the root zone of cultured plants as active phosphorous mobilizing bacteria (Collection of useful soil microorganisms of the Institute of Agricultural Microbiology and Agro-Industrial Manufacture NAAS). Paenibacillus polymyxa KB phosphorous mobilizing bacteria biological agents of Polymyxobakteryn microbial preparation [9], which is recommended 
for application in growing technology of some cultured crops, were used as a positive control.

Preservation of bacterial cells on bacterized seeds of winter wheat was controlled by wiping-off bacteria from seeds' surface, their subsequent inoculation on meat-peptone agar (MPA) and record using hemocytometer (Goryaev's chamber) [10]. Experiments were conducted on the first day of seeds bacterization and monthly for 150 days.

Ecize of $R$. radiobacter bacteria in the rhizosphere of winter wheat plants of Poliska 90 variety was studied in small pot experiments on leached light loam meadow-chernozem soils (humus $-2.12 \%$, easily hydrolyzed nitrogen $-95.2 \mathrm{mg} / \mathrm{kg}$, phosphorus $-226 \mathrm{mg} /$ $\mathrm{kg}, 108 \mathrm{mg} / \mathrm{kg}$ of exchangeable potassium, pHsalt $=5.30$ ) on the experimental fields of the Institute of Agricultural Microbiology and Agro-Industrial Manufacture NAAS. The total area of experiment was 92.2 sq.m, repetition of the experiment - four-fold.

Scheme of the experiment with winter wheat (Poliska 90 variety):

1. Without bacterization (control).

Bacterization:

2. Paenibacillus polymyxa KB.

3. Rhizobium radiobacter 599.

4. R. radiobacter 1333 .

5. $R$. radiobacter 5006 .

6. $R$. radiobacter 5718 .

Inoculation of winter wheat seeds was performed with the suspension of bacterial cells of studied phosphorous mobilizing strains at the rate of 0.5 million cells per seed in accordance to SOU 01.11-37-782 [11]. The labeled strains of bacteria $R$. radiobacter, adapted to streptomycin by the Zibalskiy method [12] were used in the studies.

Record of streptomycin resistant bacteria in the root zone of winter wheat plants was carried out in the tillering (at autumn), booting and heading stages. Bacteria were counted using corresponding culture dilutions method on nutrient media MPA, containing $2 \mathrm{~g} / 1$ of streptomycin with sodium salt of levorin (for inhibition of micromycetes growth) using method of antibiotic resistant variants [13]. Seeds without bacterization were used as control keeping the record number of indigenous bacteria resistant to streptomycin.

Small pot experiments were planned and conducted in accordance to Dospehov [14].

Results and discussion. It was established that within the first month after bacterization there were at least 200 thousand bacterial cells persisted on the seed surface (Fig. 1). $R$. radiobacter 599 and $R$. radiobacter 5006 had most number of the bacteria preserved, 240 thous. / seed and 200 thous. / seed, correspondingly. Within two months more than 100 thous. of bacterial cells / seed have remained on seeds. Subsequently, the number of bacterial cells of $R$. radiobacter on seed have decreased. Nevertheless, the life period of the increased number of inoculant cells on the seeds should be sufficient for development and naturalization of bacteria in root zone of plants.

The results obtained have demonstrated that a large number of bacterial cells of $R$. radiobacter had preserved on winter wheat seeds for two months. 


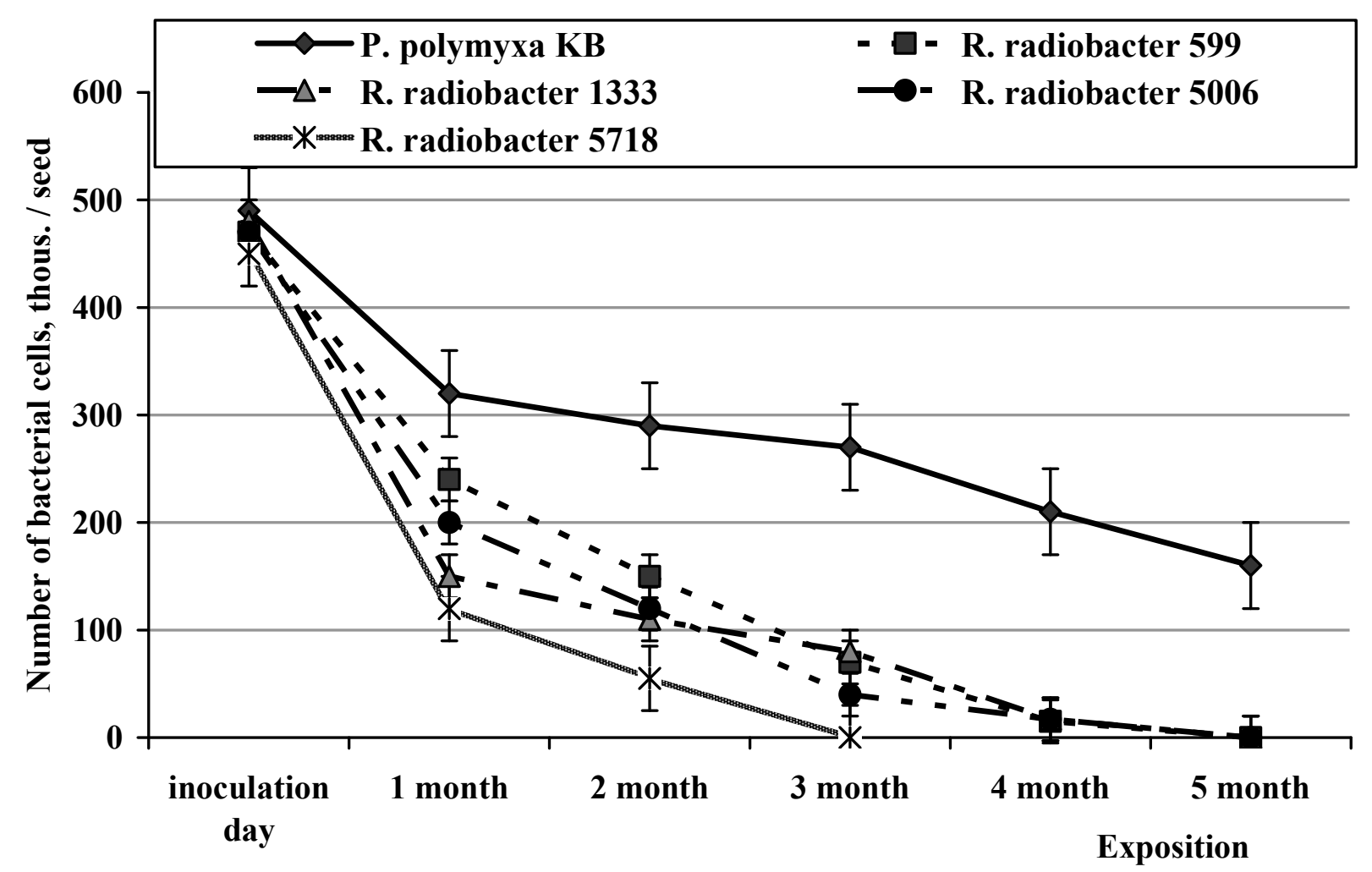

FIGURE 1. Preservation dynamics of phosphorous mobilizing bacteria cells on bacterized seeds of winter wheat (Poliska 90 variety).

Assumption on the direct and indirect positive effects of introduced bacteria on plants can be made only if inoculants ecize and develop in the root zone of plants. This caused the examination of the ecize rates of $R$. radiobacter in the root zone of inoculated winter wheat plants.

The results obtained have demonstrated that a large number of bacterial cells of $R$. radiobacter had preserved on winter wheat seeds for two months.

Assumption on the direct and indirect positive effects of introduced bacteria on plants can be made only if inoculants ecize and develop in the root zone of plants. This caused the examination of the ecize rates of $R$. radiobacter in the root zone of inoculated winter wheat plants.

It was shown that rhizosphere soil of bacterized winter wheat plants has many streptomycin resistant bacteria, especially at tillering stage - up to 1021 thous. / g soil (in variant with $R$. radiobacter 1333 strain) (Fig. 2). During later organogenesis stages booting and heading, the number of inoculant cells in the root zone of plants had gradually decreased and was 559 thous. / g soil and 239 thous. / g soil, respectively. At the same time, the number of bacteria naturally resistant to streptomycin was significantly lower and had slightly varied during the study $(219-233$ thous. / g soil).

It was shown that by the number of streptomycin resistant bacteria, the variants with plants inoculated with $R$. radiobacter had not inferior variant of $P$. polymyxa KB. 


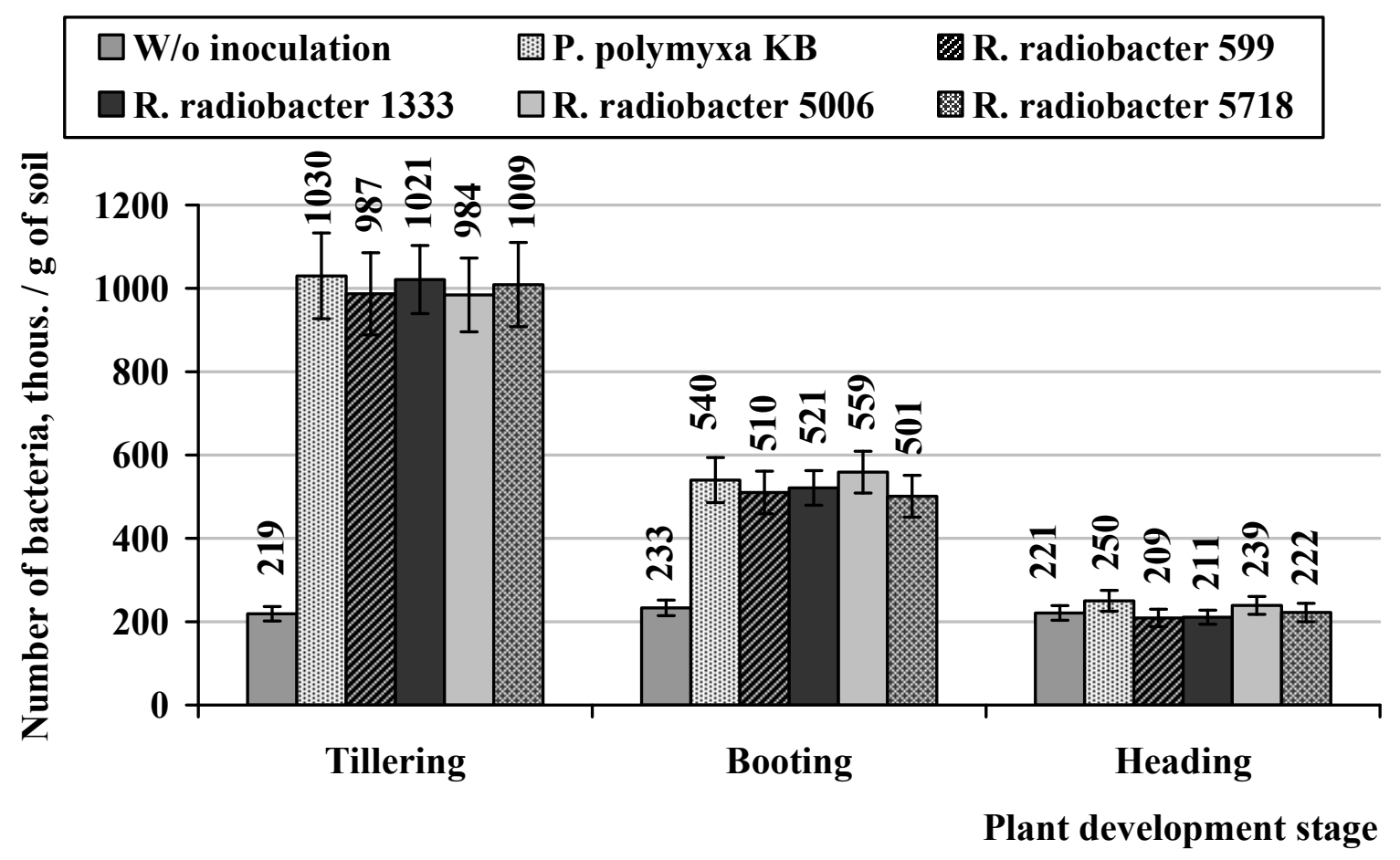

FIGURE. 2. Number of streptomycin resistant bacteria in the root zone of winter wheat plants (Poliska 90 variety)

The high number of introduced bacterial cells in the root zone of winter wheat plants is a very important index, since it is known, that during the early period of crop vegetation wheat plants needs for phosphorus is particularly high, with its absorption rate per unit of dry weight higher than at later developmental stages [15]. Despite the relative decrease of introduced microorganisms' number, high initial bacterial pool improves plant growth conditions by both dissolving hard soil phosphates [16] and production of phytohormones [17].

Therefore, the period of active phosphorus uptake of by plants is consistent with active development of phosphorous mobilizing bacteria introduced into the root zone of winter wheat plants, indicating a high agronomic value of seeds bacterization with $R$. radiobacter.

Thus, it was established that phosphorous mobilizing bacteria $R$. radiobacter can preserve on bacterized seeds for two months with the bacterial count of more than 100 thousand cells / seed and can ecize and develop in the root zone of winter wheat plants. The results obtained may might be interesting not only from the scientific point of view but also for the practical application of studied microorganisms in the technologies of winter wheat cultivation. In addition to the bacteria impact on the production process of winter wheat crop, the ability of bacterial cells to persist on seeds surface for two months is of a big importance creating favorable conditions for pre-sowing seeds inoculation. 